\title{
Studi Tata Kelola Perusahaan yang Baik melalui Kinerja Perusahaan: Studi Pemetaan Sistematik
}

\begin{abstract}
Authors:
Nurjamilah $^{1}$

Muhamad Rizal ${ }^{2}$

Ria Arifianti ${ }^{3}$

Affiliations:

1,2,3Administrasi Bisnis,

Fakultas Ilmu Sosial dan Ilmu

Politik, Universitas

Padjadjaran, Bandung,

Indonesia.

Corresponding Author:

Nurjamilah

Emails:

1nurjamilah18001@mail.unpad. ac.id

Abstract. The implementation of Good Corporate Governance is a concept that emphasizes the importance of the rights of shareholders to obtain information correctly, accurately, and on time. But a thorough understanding of the state-of-art of Good Corporate Governance is needed. Therefore, this article aims to classify, identify scientific publications and conduct thematic analyzes of the current literature to create extensive and detailed understanding in the field of Good Corporate Governance. The research method was carried out by means of the Systematic Mapping Study (SMS) to study scientific publications in the field of Good Corporate Governance which were based on the focus and type of research from time to time. The results of this study resulted in the categorization and quantification of the Good Corporate Governance study in various dimensions as well as an overview of current research topics and trends.
\end{abstract}

${ }^{2}$ m.rizal@unpad.ac.id

3r.arifianti@unpad.ac.id

Article History:

Received: September 04, 2018

Revised : October 18, 2018

Accepted: November 29, 2018

How to cite this article:

Nurjamilah, N., Rizal, M., \&

Arifianti, R. (2018). Studi Tata

Kelola Perusahaan yang Baik

melalui Kinerja Perusahaan:

Studi Pemetaan Sistematik.

Organum: Jurnal Saintifik

Manajemen dan Akuntansi,

1(2), 59-73. doi:

https://doi.org/10.35138/organu

$\underline{\text { m.v1i2.36 }}$

Journal Homepage:

ejournal.winayamukti.ac.id/ind

ex.php/Organum

\section{Copyright:}

(c) 2018. Published by Organum: Jurnal Saintifik Manajemen dan Akuntansi. Faculty of Economics and Business. Winaya Mukti University.

Keywords: Good Corporate Governance; firm performance; systematic mapping study.

Abstrak. Pelaksanaan Good Corporate Governance merupakan konsep yang menekankan pentingnya hak pemegang saham untuk memperoleh informasi dengan benar, akurat, dan tepat waktu. Namun pemahaman menyeluruh tentang state-of-art dari Good Corporate Governance diperlukan. Oleh karena itu, artikel ini bertujuan untuk mengklasifikasikan, mengidentifikasi publikasipublikasi ilmiah dan melakukan analisis tematik terhadap literatur terkini guna menciptakan pemahaman yang ekstensif dan terperinci dibidang Good Corporate Governance. Metode penelitian dilakukan dengan cara Systematic Mapping Study (SMS) untuk menelaah publikasi ilmiah dibidang Good Corporate Governance yang dihasilkan berdasarkan fokus dan tipe riset dari waktu ke waktu. Hasil penelitian ini menghasilkan kategorisasi dan kuantifikasi studi Good Corporate Governance dalam berbagai dimensi serta ikhtisar topik dan tren penelitian saat ini.

Kata kunci: Tata kelola perusahaan; kinerja perusahaan; studi pemetaan sistematik.

\section{Pendahuluan}

$\mathrm{B}$ erbagai studi tentang tata kelola perusahaan dan struktur kepemilikan telah terjadi beberapa kegagalan perusahaan dengan masalah terutama yang berasal dari implementasi yang tidak tepat dari prinsip tata kelola yang baik (Doost dan Fishman, 2004; Mardjono, 2006 dalam Ahmed Haji (2015) Fenomena ini menarik banyak kepentingan publik karena kepentingannya yang nyata bagi kesehatan ekonomi organisasi perusahaan dan masyarakat luas, terutama ketika skandal tata kelola perusahaan telah mendominasi berita utama bisnis dalam 
beberapa tahun terakhir. Akibatnya, perhatian pemerintah, organisasi, dan peneliti berubah menuju penyelidikan dampak tata kelola perusahaan dan struktur kepemilikan pada perusahaan kinerja.

Penelitian telah menunjukkan bahwa atribut tata kelola perusahaan dan struktur kepemilikan pola sebagai penentu utama kinerja perusahaan menurut Sun et al., 2002; Leng, 2005; Chen et al., 2005; Mak dan Kusnadi, 2005; Maury, 2006; Che Haat et al., 2008; Clacher et al., 2008; Yammeesri dan Herath, 2010; Cheung et al., 2011; Lam dan Lee, 2012; Kumar dan Singh, 2013 dalam Ahmed Haji (2015). Namun, bukti empiris yang ada sebagian besar berfokus pada periode waktu tertentu dan karenanya pengamatan empiris tidak dapat disimpulkan menurut Belkhir, 2009; Yammeesri dan Herath, 2010; Ahmed Sheikh et al., 2013. Sementara sejumlah penelitian mendukung gagasan bahwa atribut tata kelola perusahaan meningkatkan kinerja perusahaan menurut Che Haat et al., 2008; Rashid dan Islam, 2013; Siagian et al., 2013, sedangkan penelitian lain menemukan kebalikannya menurut Yammeesri dan Herath, 2010. Hasil yang bertentangan dari penelitian sebelumnya dapat disebabkan oleh kerangka waktu yang telah mereka periksa dan sampai batas tertentu, pendekatan metodologis dan ukuran kinerja yang telah mereka gunakan menurut Kyereboah-Coleman, 2007 dalam Ahmed Haji (2015).

Demikian pula, garis penelitian tata kelola lain meneliti tata kelola perusahaan variabel yang terkait dengan kinerja perusahaan menurut Mohd Ghazali, 2010; Yammeesri dan Herath, 2010; Lam dan Lee, 2012; Ujunwa, 2012; Ahmed Sheikh et al., 2013. Sementara garis penelitian ini menghasilkan hasil yang tidak meyakinkan, studi telah menunjukkan bahwa perusahaan yang dikelola dengan baik memiliki kinerja perusahaan yang lebih tinggi menurut pendapat Che Haat et al., 2008; Siagian et al., (2013). mempelajari apakah perusahaan dengan tata kelola yang lebih efisien struktur memiliki kinerja yang lebih tinggi. Dalam penelitian tersebut menemukan bahwa perusahaan dengan efisien struktur tata kelola jauh lebih baik daripada perusahaan sejenis. Sebagai tambahan, Williams (2006) dan Che Haat et al. (2008) dalam Ahmed Haji (2015) menyimpulkan, dalam studi masing-masing, bahwa ada adalah hubungan positif antara praktik tata kelola perusahaan yang baik dan nilai perusahaan sedangkan menurut Siagian et. al. (2013) adanya hubungan positif yang signifikan antara yang baik praktik tata kelola perusahaan dan nilai perusahaan perusahaan Indonesia. Selain itu, penelitian perusahaan dalam situasi krisis juga secara konsisten mengungkapkan hubungan yang jelas. Sehingga istilah GCG semakin populer dan mendapatkan tempat di bidang hukum korporasi karena terwujud dalam dua keyakinan, yaitu: Pertama, GCG merupakan salah satu kunci sukses perusahaan untuk tumbuh dan menguntungkan dalam jangka panjang, sekaligus memenangkan persaingan bisnis global, terutama bagi perusahaan yang telah mampu berkembang sekaligus menjadi terbuka. Kedua, krisis ekonomi dunia, di kawasan Asia dan Amerika Latin yang diyakini muncul karena kegagalan penerapan GCG.

Oleh karena itu, untuk mendapatkan perspektif penelitian yang ada, peneliti melakukan studi pemetaan sistematis (systematic mapping study). Studi ini merupakan tinjauan literatur dengan menggunakan systematic mapping study (SMS) mengenai Good Corporate Governance, meskipun ada beberapa tinjauan literatur terkait Good Corporate Governance yang dilakukan, namun hanya sedikit yang membahas spesifik systematic mapping study (SMS) mengenai Good Corporate Governance dalam upaya meningkatkan kinerja perusahaan. Maka, tujuan dari penelitian ini untuk menyediakan peta literatur pada 
database sehingga mencapai hasil yang bermanfaat bagi penggunaan praktis maupun akademisi untuk mengidentifikasi kesenjangan penelitian (gaps) di masa yang akan datang menurut Ahmed Haji (2015).

\section{Kajian Literatur}

Corprate Governance menurut Tunggal (2012:24) merupakan sistem yang mengatur, mengelola dan mengawasi proses pengendalian usaha untuk menaikan nilai saham, sekaligus sebagai bentuk perhatian kepada stakeholders, karyawan, dan masyarakat sekitar.

Menurut Forum for Corporate Governance in Indonesia/FCGI (2001) mendefinisikan Corporate Governance sebagai seperangkat peraturan yang menetapkan hubungan antara pemangku kepentingan pengurus, pihak kreditur, pemerintah, karyawan serta para pemegang kepentingan internal dan eksternal lainnya sehubungan dengan hakhak dan kewajiban mereka, atau dengan kata lain sistem yang mengarahkan dan mengendalikan perusahaan, sedangkan menurut Agoes (2011:101) mendefinisikan Tata Kelola Perusahaan yang baik (GCG) merupakan suatu sistem yang mengatur hubungan peran Dewan Komisaris peran Direksi, pemegang saham, dan pemangku kepentingan lainnya. Tata kelola perusahaan yang baik juga disebut sebagai proses yang transparan atas penentuan tujuan perusahaan, pencapainya dan penilaian kinerjanya.

Sedangkan pada Badan Usaha Milik Negara (BUMN) di Indonesia, penerapan praktik Good Corporate Governance dipertegas dengan keluarnya Keputusan Manteri BUMN Nomor: Kkep117/M/MBU/2002 pasal 1 tentang penerapan praktik Good Corporate Governance pada Badan Usaha Milik Negara (BUMN), merupakan suatu proses dan stuktur yang dipergunakan oleh organ BUMN untuk meningkatkan keberhasilan usaha dan akuntabilitas perusahaan guna mewujudkan nilai pemegang saham dalam jangka panjang dengan tetap memperhatikan kepentungan stakeholders lainnya berlandaskan peraturan perundang-undangan dengan nilai etika.

Dari beberapa definisi teori diatas dari Tunggal (2012:24), Forum for Corporate Governance in Indonesia/FCGI (2001), Agoes (2011:101), dan Keputusan Menteri BUMN No:Kep117M/MBU/2002 pasal 1tentang praktik Good Corporate Governance pada Badan Usaha Milik Negara (BUMN) maka dapat disimpulkan bahwa Good Corporate Governance adalah suatu sistem yang mengatur, mengelola, dan mengawasi pengendalian usaha untuk keberhasilan usaha perusahaan sebagai bentuk perhatian kepada stakeholders serta mengatur hubungan dan tanggung jawab antara karyawan, kreditur serta para pemegang kepentingan internal dan eksternal dalam mengendalikan perusahaan demi tercapainya tujuan perusahaan yang ingin dicapai oleh para pihak-pihak yang berkepentingan dan memperhatikan kepentingan para stakeholder sesuai dengan aturan dan undang-undang.

\section{Metode Penelitian}

Tujuan dari studi pemetaan sistematis ini adalah untuk membentuk latar belakang riset lebih lanjut serta mendapatkan wawasan mendalam tentang kajian Good Corporate Governance di bidang Firm Performance. Dalam penelusuran peneliti menggunakan database electronic International untuk menemukan artikel yang membahas tentang Good Corporate Governance di bidang Firm Performance. Studi SMS merupakan metode yang tepat sebagai pendekatan studi literatur karena didukung dengan 1.088 artikel terkait Good Corporate Governance dari penelusuran di Emerald insight electronic database (Kitchenham, 2011; Petersen et 
al., 2008). Untuk mecapai tujuan penelitian, dibutuhkan pertanyaan penelitian (Research Questions) lebih luas untuk menemukan temuan-temuan yang akurat dan relevan pada database electronic. Secara keseluruhan peneliti menganalisa hasil pencarian yang relevan dengan kajian Good Corporate Governance berdasarkan rumusan pertanyaan utama, yang meliputi:

1. RQ1: Bagaimana fokus penelitian pada topik yang diteliti?

2. RQ2: Bagaimana tipe artikel dan metode penelitian yang digunakan?

3. RQ3: Bagaimana perkembangan topik disetiap negara dari waktu ke waktu?

Penelitian ini menggunakan Systematic Mapping Study (SMS) yang mana merupakan studi sekunder. SMS berakar pada Study Literature Review (SLR) yang dikenalkan pada riset-riset teknologi informasi (Kitchenham.B, 2011). Penelitian dengan pendekatan SLR bertujuan untuk mengidentifikasi, mengevaluasi, dan menafsirkan semua sumber literatur yang tersedia dan relevan, terkait dengan pertanyaan penelitian yang telah dirumuskan (Kitchenham, 2011; Petersen et al., 2008; Barbosa dan Alves, 2011; Banaeianjahromi \& Smolander, 2016). Alasan paling umum untuk melakukan SLR adalah pertama, meringkas tentang topik tersebut; kedua, mengidentifikasi kesenjangan dalam penelitian dan memberikan saran untuk penyelidikan di masa yang akan datang; dan ketiga, memposisikan kegiatan penelitian baru dengan memberi latar belakang (Kitchenham, 2011). SMS diterapkan untuk menguraikan jenis aktivitas penelitian yang telah dilakukan dalam penelitian ini. SMS menjelaskan penelitian pada tingkat tinggi dan memetakan penelitian dari pada menyelidiki pertanyaan penelitian secara rinci (Petersen et al., 2008). Dengan kata lain, SMS dapat dianggap sebagai metode untuk mendapatkan gambaran umum tentang area penelitian tertentu (Kitchenham et al., 2011), karena penelitian SMS menggali informasi secara terperinci.

\section{Langkah pencarian}

Untuk menambah keakuratan studi SMS, proses pencarian dan analisis harus seakurat mungkin. Dengan demikian, pada bagian ini mencirikan proses pemilihan sumber data, strategi penerapan untuk membuat string pencarian, dan menentukan kriteria eksklusi dan inklusi. Penelitian ini mengadopsi proses pencarian dari penelitian Petersen et al. (2008) dan Banaeianjahromi dan Smolander (2016). Dalam proses ini, setiap langkah memiliki hasil dan peta sistematis (Systematic Mapping) adalah hasil akhir dari proses pemetaan. Pada gambar 1 peneliti mengilustrasikan proses SMS lengkap yang digunakan dalam penelitian ini, peneliti mengacu pada penelitian yang dilakukan dan sesuai instruksi oleh Kitchenham (2011) dan Petersen et al (2008). Peneliti melakukan pencarian secara online pada database elektronik Emerald Insight. 


\section{Gambar 1. Proses SMS (Pencarian)}

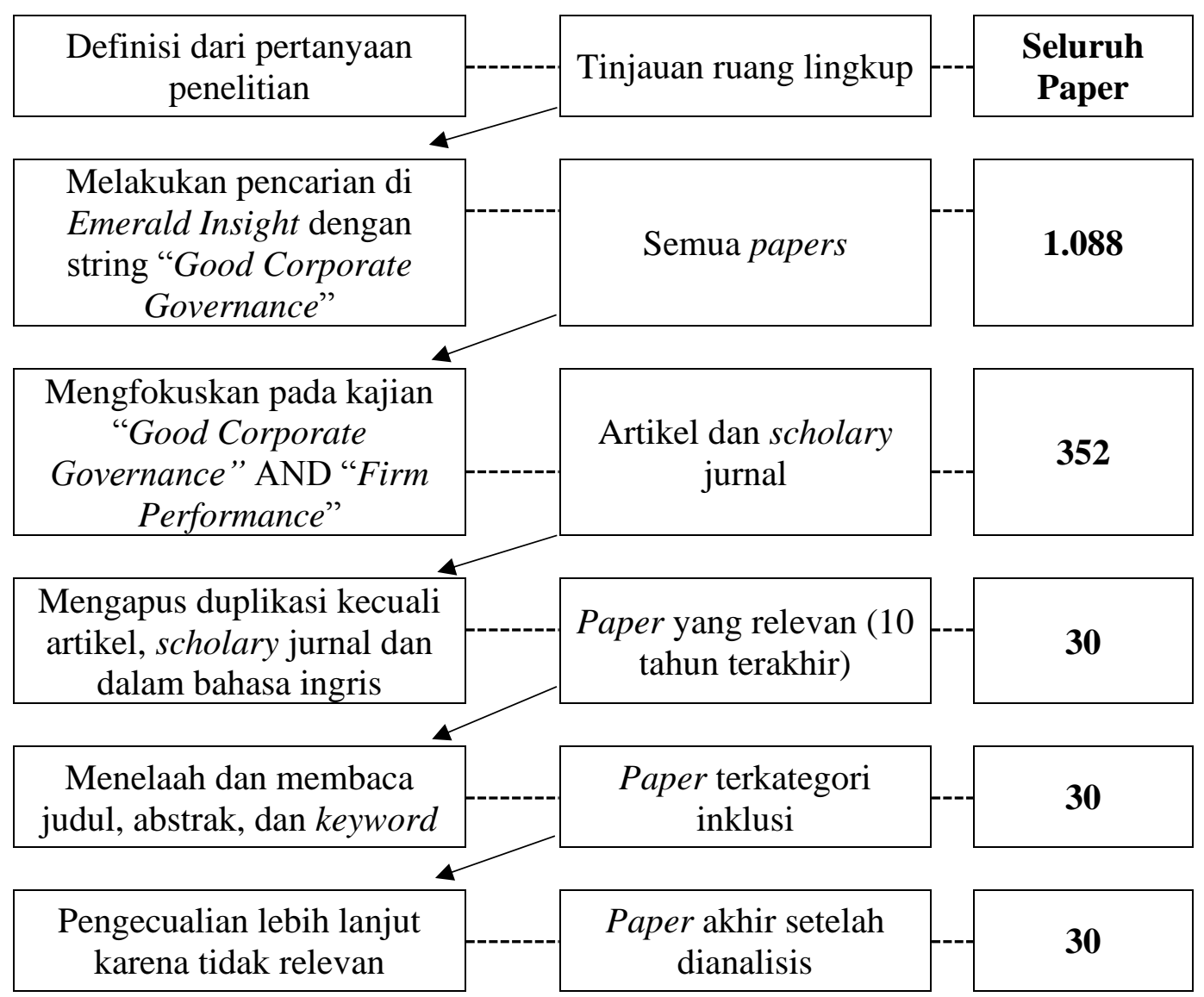

Sumber: (Kitchenham, 2011; Petersen et al, 2008; Banaeianjahromi dan Smolander, 2016)

String pencarian atau kata kunci pencarian dibuat dengan menggunakan strategi dari Banaeianjahromi dan Smolander (2016) dengan mengacu dari penelitian Barbosa and Alves (2011). Langkah pertama adalah mendefenisikan kata kunci utama. Langkah kedua adalah memeriksa penelitian-penelitian yang sudah dikenal dibidang Good Corporate Governance. Ketiga yaitu mencari bentuk kata kunci alternatif untuk digunakan pada proses pencarian, Menurut Banaeianjahromi dan Smolander (2016) langkah terakhirnya menggunakan operator Boolean yang fungsinya untuk mensintesis menjadi satu string pencarian, namun pada penelitian ini tidak menggunakan operator Boolean AND ataupun $O R$ karena pada tahap ketiga peneliti menemukan bahwa apabila kombinasi stringnya adalah "Good Corporate Governance" OR "Firm
Performance" peneliti menemukan 11.405 hasil. Namun apabila string pencarian hanya tidak menggunakan Boolean hasil yang ditemukan dengan string "Good Corporate Governance" ditemukan sebanyak 1.088 hasil. String pencarian di atas diterapkan untuk pencarian pada semua bagian artikel, seperti judul, abstrak, kata kunci pada database elektronik Emerald Insight. Proses pencarian dimulai pada tanggal 01 April 2018 (Barbosa \& Alves, 2011).

Selanjutnya, langkah untuk menentukan kategori artikel pengecualian yang disebut kriteria eksklusi dan artikel inklusi yang merupakan salah satu kegiatan studi pemetaan untuk tidak mengikutsertakan artikel yang tidak relevan dan mencakup artikel yang relevan (Petersen et al., 2008). Pada penelitian ini, kami merumuskan kriteria 
eksklusi dan inklusi untuk mempermudah pemetaan (Tabel 1)

\section{Langkah pengklasifikasian}

Pada proses pemetaan sistematis, untuk menganalisis dan mengklasifikasikan artikel yang sudah diseleksi berdasarkan kriteria, peneliti merumuskan tiga aspek untuk pengklasifikasian artikel yang ditemukan yang telah relevan. Pada kategori pertama kami mengelompokkan artikel berdasarkan fokus penelitian (research focus) dengan acuan Petersen et al. (2008). Kategori kedua mendefinisikan tipe artikel (paper type) berdasarkan klasifikasi yang disajikan dalam Wieringa et al. (2005). Selanjutnya pada kategori ketiga berdasarkan metode penelitian dengan rujukan dari penelitian. Tabel 2 menjelaskan ketiga kategori pada proses klasifikasi pada penelitian ini.

\section{Tabel 1. Kriteria Inklusi dan Eksklusi}

\section{Inklusi}

1. Penelitian yang berfokus pada penelitian keunggulan kompetitif

2. Bahasa Inggris

3. Hanya artikel dan scholary journals

4. Makalah yang sudah melewati peer reviewed

\section{Eksklusi}

1. Makalah yang tidak membahas tentang keunggulan kompetitif

2. Bahasa lain selain bahasa Inggris

3. Disertasi, tesis, bagian buku, deskripsi produk, presentasi, laporan kerja, literatur perdagangan, catatan editorial, literatur yang tidak jelas

4. Makalah yang belum melewati peer reviewed

5. Penelitian duplikat

Sumber: (Barbosa \& Alves, 2011; Banaeianjahromi dan Smolander, 2016)

\section{Tabel 2. Kategori Klasifikasi}

\begin{tabular}{|c|c|}
\hline Paper Type & Penjelasan \\
\hline $\begin{array}{l}\text { Validation } \\
\text { Research }\end{array}$ & $\begin{array}{l}\text { Metode investigasi baru dan belum diterapkan dalam praktik. (percobaan } \\
\text { / observasi) }\end{array}$ \\
\hline $\begin{array}{l}\text { Evaluasi } \\
\text { Research }\end{array}$ & $\begin{array}{l}\text { Metode investigasi diimplementasikan dalam praktek dan disajikan } \\
\text { dalam metode evaluasi }\end{array}$ \\
\hline $\begin{array}{l}\text { Solution } \\
\text { Proposal }\end{array}$ & $\begin{array}{l}\text { Solusi untuk masalah diajukan, usulan solusi ini bisa berupa pendekatan } \\
\text { baru atau berlaku dan pendekatan yang ada. }\end{array}$ \\
\hline $\begin{array}{l}\text { Philosophical } \\
\text { Paper }\end{array}$ & $\begin{array}{l}\text { Penelitian ini memperkenalkan perspektif baru tentang sesuatu yang ada } \\
\text { dengan menggunakan taksonomi atau kerangka konseptual. }\end{array}$ \\
\hline Methods & Penjelasan \\
\hline $\begin{array}{l}\text { Metode } \\
\text { Kualitatif }\end{array}$ & $\begin{array}{l}\text { Metode Kualitatif disajikan Rapid Assessment Process, data sekunder, } \\
\text { etnografis, Focus Group Discussions, In-Depth Interviews, buku harian } \\
\text { dan analisa bahasa. }\end{array}$ \\
\hline Methods & Penjelasan \\
\hline $\begin{array}{l}\text { Metode } \\
\text { Kuantitatif }\end{array}$ & $\begin{array}{l}\text { Metode Kuantitatif disajikan rancangan sampel, hipotesis dan } \\
\text { pengujiannya, yang kesemuanya berupa perumusan statistik. }\end{array}$ \\
\hline Mix Methods & $\begin{array}{l}\text { Mix methods penelitian adalah metode yang memadukan pendekatan } \\
\text { kualitatif dan kuantitatif dalam hal metodologi (seperti dalam tahap } \\
\text { pengumpulan data), dan kajian model campuran memadukan dua } \\
\text { pendekatan dalam semua tahapan proses penelitian (Abbas, 2010) }\end{array}$ \\
\hline $\begin{array}{l}\text { Research } \\
\text { Focus }\end{array}$ & Penjelasan \\
\hline
\end{tabular}




\begin{tabular}{|c|c|}
\hline $\begin{array}{l}\text { Corporate } \\
\text { Governance }\end{array}$ & $\begin{array}{l}\text { Rangkaian proses, kebiasaan, kebijakan, aturan, dan institusi yang } \\
\text { memengaruhi pengarahan, pengelolaan, serta pengontrolan suatu } \\
\text { perusahaan atau korporasi. }\end{array}$ \\
\hline $\begin{array}{l}\text { Ownership } \\
\text { Structure }\end{array}$ & Merupakan bagian dari proporsi kepemilikan \\
\hline $\begin{array}{l}\text { Board } \\
\text { Independence }\end{array}$ & $\begin{array}{l}\text { Pihak luar yang diangkat berdasarkan keputusan Rapat Umum } \\
\text { Pemegang Saham (RUPS). }\end{array}$ \\
\hline $\begin{array}{l}\text { Financial } \\
\text { Crisis }\end{array}$ & $\begin{array}{l}\text { Krisis finansial digunakan untuk berbagai situasi dengan berbagai } \\
\text { institusi atau aset keuangan kehilangan sebagian besar nilai mereka. } \\
\text { Pada abad ke-19 dan ke-20, banyak krisis finansial berhubungan dengan } \\
\text { kepanikan perbankan dan resesi }\end{array}$ \\
\hline Board Size & $\begin{array}{l}\text { Board size yang terdiri dari direksi, komisaris independen dan komisaris } \\
\text { non-independen yang diukur dengan menjumlahkan total personel dalam } \\
\text { dewan direksi dengan total personel pada dewan komisaris independen } \\
\text { dan non independen }\end{array}$ \\
\hline $\begin{array}{l}\text { Board } \\
\text { Structure }\end{array}$ & $\begin{array}{l}\text { Struktur organisasi perusahaan dapat diartikan sebagai sebuah garis } \\
\text { bertingkat (hierarki), yang berisi komponen-komponen penyusun } \\
\text { perusahaan. }\end{array}$ \\
\hline $\begin{array}{l}\text { Managerial } \\
\text { Ownership }\end{array}$ & $\begin{array}{l}\text { Kepemilikan manajerial merupakan pemisahan kepemilikan antara } \\
\text { pihak outsider dengan pihak insider }\end{array}$ \\
\hline $\begin{array}{l}\text { Accounting } \\
\text { Conservatism }\end{array}$ & $\begin{array}{l}\text { Prinsip dalam pelaporan keuangan yang dimaksudkan untuk mengakui } \\
\text { dan mengukur aktiva dan laba dilakukandengan penuh kehati-hatian oleh } \\
\text { karena aktivitas ekonomi dan bisnis yang dilingkupi ketidakpastian }\end{array}$ \\
\hline Costs & $\begin{array}{l}\text { Konsep ekonomi mengenai biaya pemilik (principal) baik organisasi, } \\
\text { perseorangan atau sekelompok orang }\end{array}$ \\
\hline $\begin{array}{l}\text { Board } \\
\text { Characteristic }\end{array}$ & Kualitas tertentu atau ciri yang khas dari seseorang atau sesuatu \\
\hline Agency Theori & $\begin{array}{l}\text { Hubungan antara pemegang saham (shareholders) sebagai prinsipal dan } \\
\text { manajemen sebagai agen }\end{array}$ \\
\hline G34 & $\begin{array}{l}\text { Suatu upaya untuk meningkakan kesadaran yang signifikan dan } \\
\text { penerapan tata kelola perusahaan yang baik. }\end{array}$ \\
\hline $\begin{array}{l}\text { Block Holder } \\
\text { Identity }\end{array}$ & $\begin{array}{l}\text { Refleksi diri atau cerminan diri yang berasal dari keluarga, gender, } \\
\text { budaya, etnis dan proses sosialisasi }\end{array}$ \\
\hline & \\
\hline
\end{tabular}

Block Suatu istilah teknis yang membuat suatu akun, sebuah alamat/blok Ownership alamat IP, atau seseorang dicegah untuk melakukan penyunting

\section{Hasil dan Pembahasan}

\section{Hasil dan Pembahasan Penelitian}

Bagian ini merupakan hasil pemetaan berdasarkan dari pertanyaan penelitian. Berdasarkan hasil pemetasan dari 30 artikel mengenai Good Corporate Governance yang berfokus pada kajian Firm Performance dikelompokan dengan menggunakan aplikasi Microsoft Excel
2010 dengan kategori research focus, research locus, methods, paper type, dan perkembangan penelitian dipenjuru dunia yang dipublis oleh Emerald Insight.

\section{Fokus Penelitian (RQ1)}

Untuk menjawab RQ1, kami mengklasifikasikan 30 artikel pada area topik penelitian (research focus) dengan kategori Corporate Governance, 
Ownership Structure, Board Independence, Financial Crisis, Board Size, Board Structure, Managerial Ownership, Accounting Conservatism,
Agency Costs, Board Characteristics, Agency Theory, G34, Block Holder Identity, Block Holding, Block Ownership.

\section{Gambar 2. Fokus Penelitian}

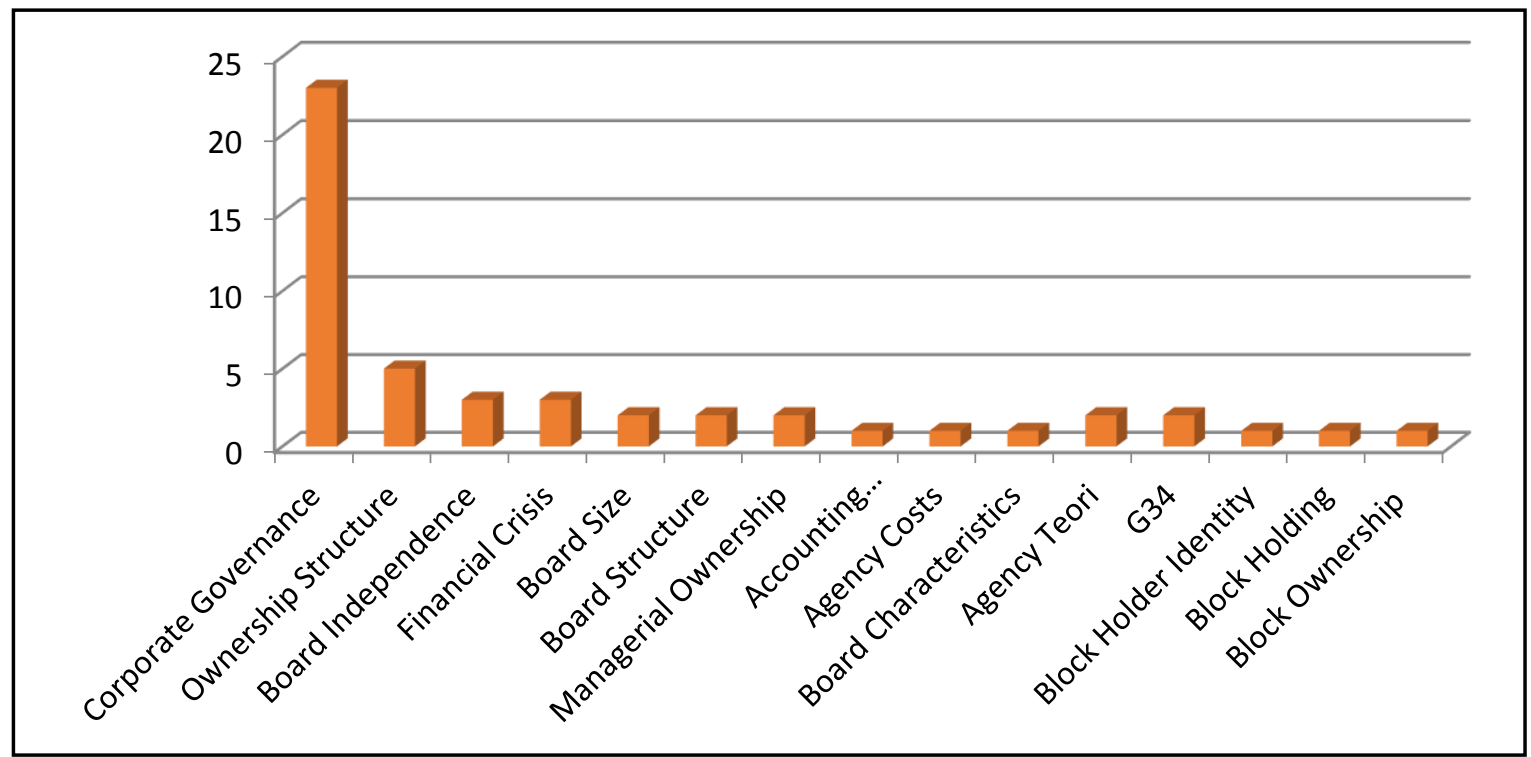

Gambar 2 merupakan persentase dari topik yang diteliti, topik yang banyak diteliti adalah penelitian dengan fokus penelitian Corporate Governance sebanyak 23 (46\%), Ownership Structure sebanyak 5 (10\%), Board Independence sebanyak 3 (6\%), Financial Crisis sebanyak $3(6 \%)$, Board Size sebanyak 2 (4\%), Board Structure 2 (4\%), Managerial Ownership sebanyak 2 (4\%), Accounting Conservatism sebanyak 1 (2\%), Agency Costs sebanyak 1 (2\%), Board Characteristics sebanyak 1 (2\%), Agency Theori sebanyak 2 (4\%),G34 sebanyak 2 (4\%), Block Holder Identity sebanyak 1 (2\%), Block Holding sebanyak
1 (2\%), Block Ownership sebanyak 1 $(2 \%)$, dari total $30(100 \%)$ penelitian.

\section{Tipe Artikel dan Metode Penelitian (RQ2)}

Tipe artikel penelitian menunjukkan klasifikasi penelitian yang mengacu pada penelitian Wieringa et al. (2005), dimana penelitian dikelompokkan menjadi empat kategori: penelitian validasi (validation research); penelitian evaluasi (evaluation research); solution proposal; philosophical papers Untuk memberikan jawaban dari RQ2, peneliti mengkategorikan 30 penelitian hasil pemetaan klasifikasi tersebut. 


\section{Gambar 4. Tipe Artikel}

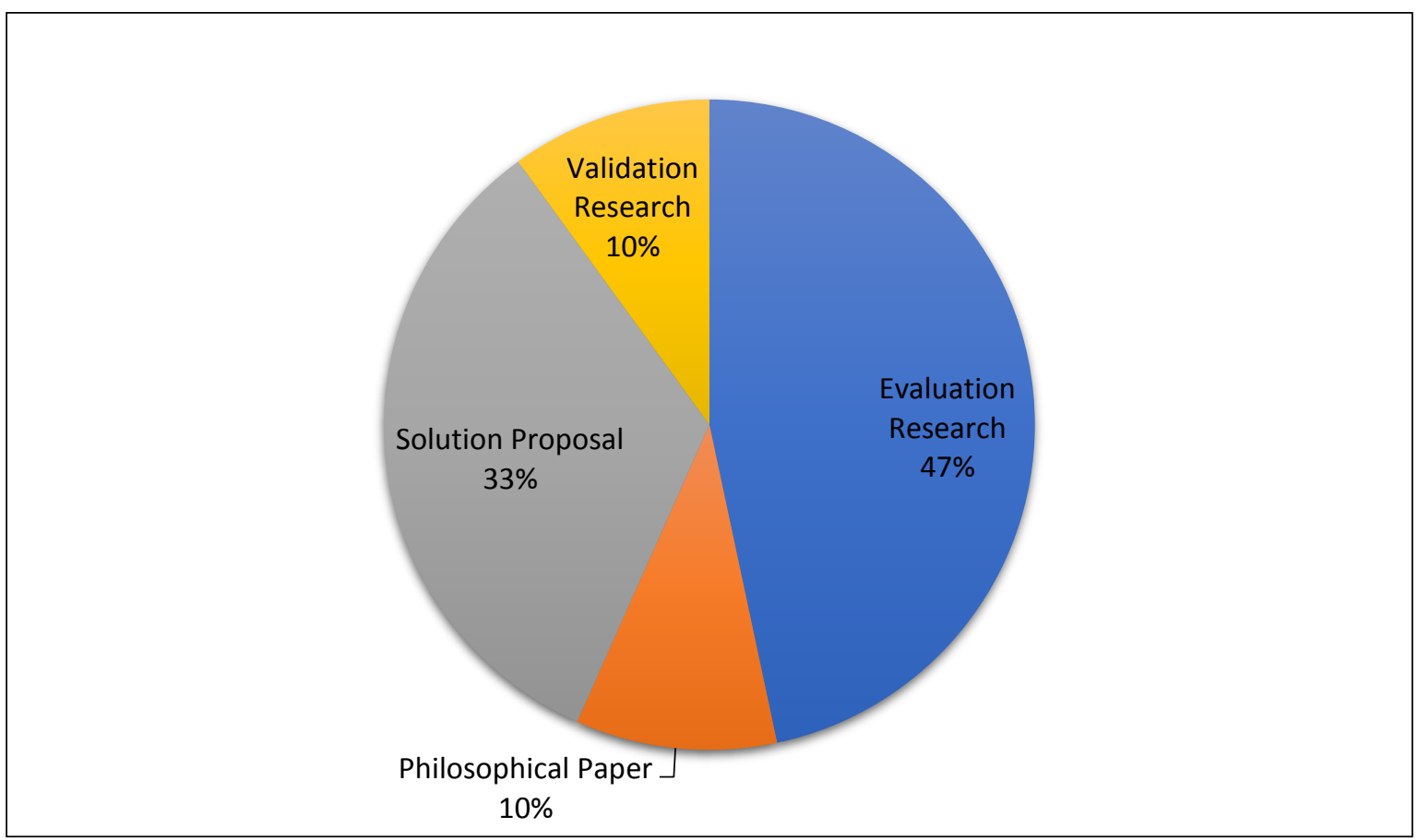

Gambar 4 menggambarkan distribusi tipe artikel (paper type) berdasarkan kategori pengklasifikasian. Berdasarkan hasil pemetaan secara sistematis (Systematic Mapping Study), tipe artikel yang paling sering digunakan adalah penelitian validasi (Evaluasi research) dengan total sebanyak 14 (47\%) penelitian. Tipe artikel yang paling sering selanjutnya adalah penelitian solusi (Solution Proposal) dengan jumlah sebanyak $10 \quad(33 \%)$ penelitian. Selanjutnya adalah tipe artikel Philosophical yang berjumlah $3(10 \%)$ dan tipe artikel validasi sebanyak $3(10 \%)$ penelitian.
Klasifikasi metode penelitian yang digunakan pada pemetaan sistematis ini adalah pendekatan kuantitatif, kualitatif dan mixed methods. Akumulasi total temuan dari 30 jurnal digambarkan pada gambar 5. Pendekatan penelitian dengan menggunakan metode kuantitatif adalah metode yang paling banyak dilakukan, karena sifatnya adalah menguji dan mengevaluasi. Total artikel yang melakukan penelitian menggunakan pendekatan kuantitatif ada sebanyak 18 $(60 \%)$ penelitian. Selanjutnya diikuti dengan atikel yang menggunakan metode kualitatif sebanyak 7 (23\%) penelitian. Dan mixed methods sebanyak 5 (17\%) penelitian. 


\section{Gambar 5. Metode Penelitian}

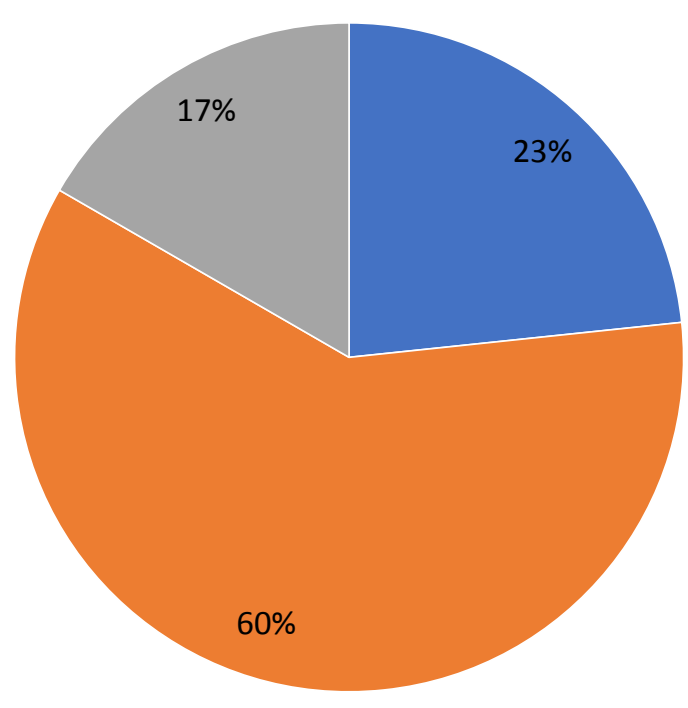

Kualitatif

Kuantitatif

Mixed Methods

Tren publikasi pada setiap Negara dari waktu ke waktu (RQ3)

Berdasarkan hasil pemetaan ditemui bahwa negara terbanyak menghasilkan penelitian pada kajian Good Corporate Governance, peneliti dominan meneliti pada Firm Performance pada perusahaan disuatu negara, dengan total temuan 30 penelitian. Selanjutnya lokus penelitian yang banyak dilakukan yaitu di negara
India dengan temuan 7 penelitian. Kemudian, di Negara Malaysia terdapat 4 penelitian, New Zealand sebanyak 4 Penelitian, Australia sebanyak 3 Penelitian, China sebanyak 3 Penelitian, Thailand sebanyak 2 Penelitian, dan negara lainnya seperti Jordan, London. Nigeria, Pakistan, Polandia, Taiwan, Vietnam sebanyak 1 penelitian per negara.

Gambar 6. Perkembangan Publikasi di setiap Negara

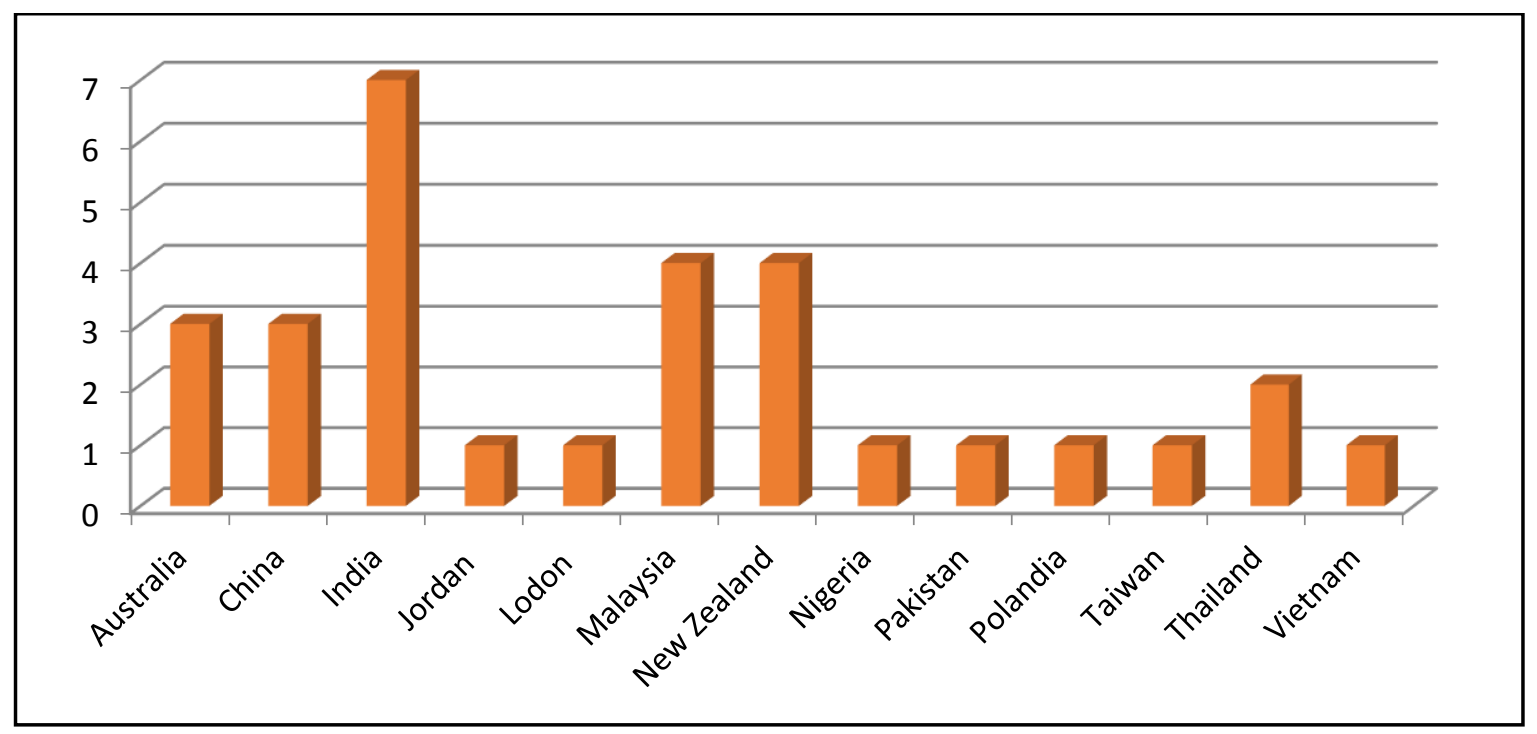


Kemudian Gambar 7 merupakan tren penelitian yang dipublikasi pada media database elektronik 8 (delapan) tahun terakhir yang dimulai pada tahun 2011 sampai dengan Tahun 2019.

Gambar 7. Perkembangan Publikasi dari Tahun ke Tahun

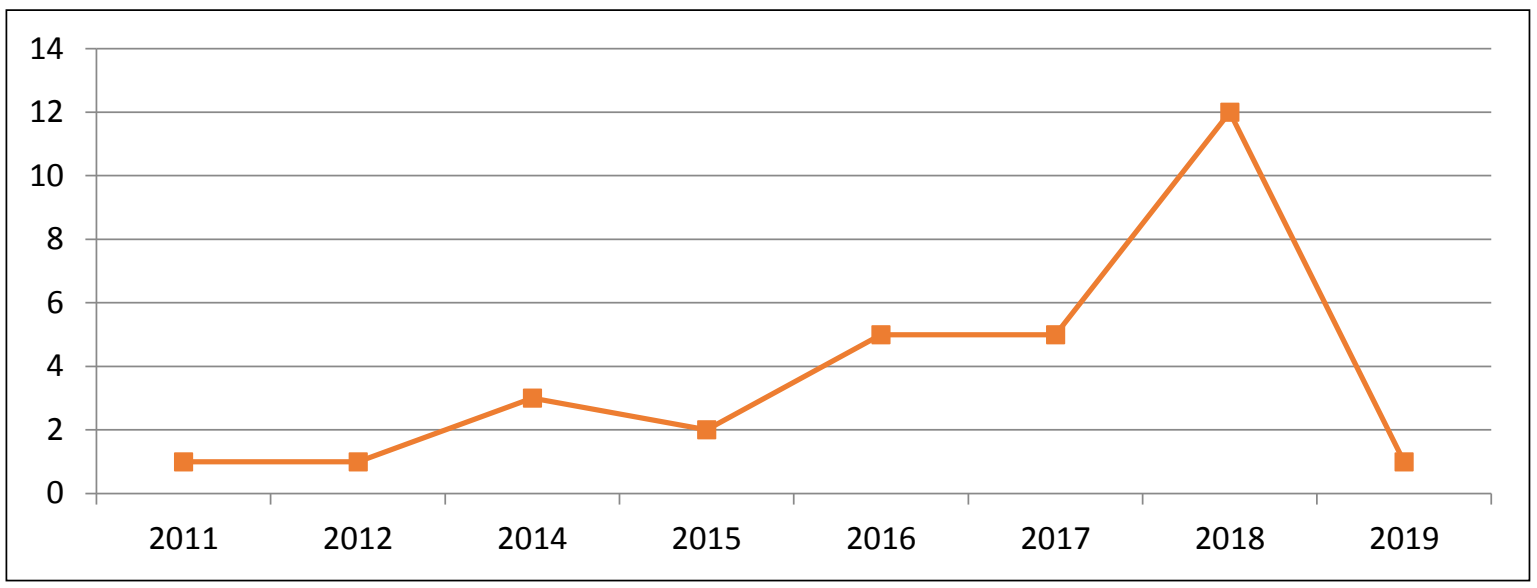

Gambar 8. Distribusi Metode Penelitian pada Jenis Penelitian

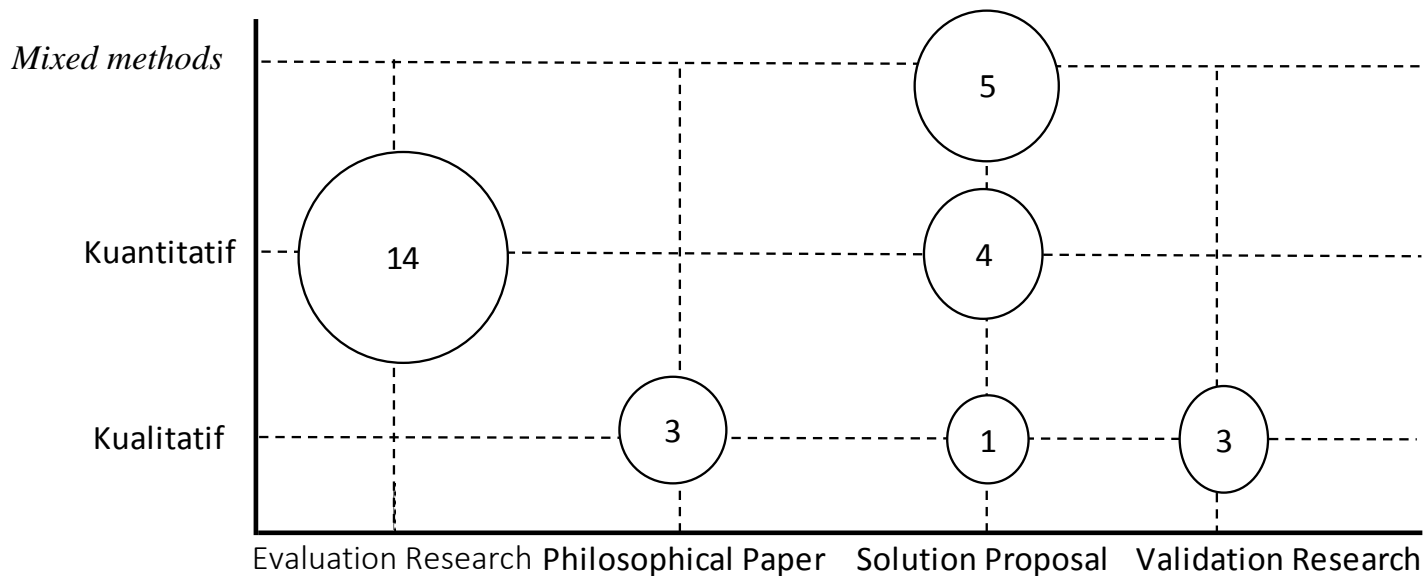

Untuk menganalisis distribusi artikel dari dimensi lain, gambar 6 menyajikan jumlah penelitian per metode penelitian yang dikombinasikan dengan jenis penelitian. Penelitian kuantitatif adalah metode penelitian utama untuk riset evaluasi yaitu sebanyak 14 penelitian. Metode penelitian kedua yang paling umum dalam studi pemetaan ini adalah metode mixed Methods pada jenis penelitian proposal solution yaitu sebanyak 5 penelitian,. Selanjutnya dapat dilihat pada jenis penelitan proposal solution merupakan penelitian yang sedikit baik dengan menggunakan metode kualitatif.

\section{Kesimpulan}

Good corporate governance merupakan suatu konsep yang berkesinambungan dan tidak dapat dipisahkan dari firm performance. Penerapan perilaku-perilaku etis untuk dapat melaksanakan good corporate governance sehingga mampu meningkatkan kinerja perusahaan. Dengan begitu, dapat ditentukan titik temu antara kepentingan perusahaan (manajemen) dan kepentingan para stakeholder sehingga pada akhirnya, dengan terlaksananya Good Corporate Governance, perusahaan akan menjalankan usaha secara berkelanjutan. 
Sehingga dalam sistem ekonomi pasar bebas seperti era sekarang, perusahaan memiliki kepercayaan dari masyarakat dan daya saing tinggi dalam beroperasi demi mewujudkan keuntungan yang maksimal baik bagi perusahaan maupun bagi semua pihak stakeholder.

Penelitian ini memetakan literature Good Corporate Governance, yang ada pada database ilmiah Emerald Insight. Motivasi utama dari studi yang dipetakan adalah untuk memberikan gambaran umum literatur yang ada tentang firm performance sebagai solusi untuk memenangkan persaingan usaha dengan meningkatkan kinerja perusahaan.

Peneliti menerapkan metode systematic mapping study (Kitchenham, 2011; Petersen et al, 2008; Banaeianjahromi dan Smolander, 2016), untuk menentukan fokus apa yang telah dikaji dalam area penelitian ini. Dari 30 artikel penelitian yang telah di petakan secara sistematik, Peneliti menyimpulkan bahwa:

1) Topik yang banyak diteliti adalah dengan fokus penelitian Corporate Governance pada kajian Firm Performance sebanyak 23 (46\%), Ownership Structure sebanyak 5 (10\%), Board Independence sebanyak 3 (6\%), Financial Crisis sebanyak 3 $(6 \%)$.

2) Tipe artikel yang paling sering digunakan adalah penelitian Evaluasi (Evaluation research) dengan total sebanyak 14 (47\%) artikel, menggunakan pendekatan penelitian kuantitatif sebanyak 18 (60\%).

3) Negara terbanyak menghasilkan penelitian pada kajian Good Corporate Governance, peneliti dominan meneliti pada Firm Performance yaitu di negara India dengan temuan 7 penelitian. Kemudian, di Negara Malaysia terdapat 4 penelitian, New Zealand sebanyak 4 Penelitian

Metode penelitian yang diadopsi SMS adalah metode penelitian praktis untuk mengenali topik yang tepat untuk diteliti, serta area mana yang diperlukan untuk lebih banyak penelitian. Hasil penelitian ini memberikan panduan untuk membantu peneliti dalam merencanakan penelitian dimasa yang akan datang melalui penemuan kesenjangan penelitian (Gaps).

\section{Daftar Pustaka}

Abbas, A., Lichtman, A. H., \& Pillai S. (2010). Cellular and Molecular Immunology (6th Ed.). W. B Saunders Company, Philadelphia.

Agoes, S. (2011). Auditing (Pemeriksaan Akuntan) oleh Kantor Akuntan Publik, (Edisi ke 3). Jakarta: Lembaga Penerbit Fakultas Ekonomi Universitas Indonesia.

Banaeianjahromi, N. \& Smolander, K. (2016). What do We Know about the Role of Enterprise Architecture in Enterprise Integration? A Systematic Mapping Study. Journal of Enterprise Information Management, 29(1), 140-164. doi: https://doi.org/10.1108/JEIM-122014-0114

Belkhir, M. (2009). Board Structure, Ownership Structure, and Firm Performance: Evidence from Banking. Applied Financial Economics, 19(19), 1581-1593. Diakses dari https://ssrn.com/abstract $=604523$

Chen, Z., Cheung, Y. L., Stouraitis, A., \& Wong, A. W. S. (2005). Ownership Concentration, Firm Performance, and Dividend Policy in Hong Kong. Pacific-Basin Finance Journal, 13(4), 431-449. doi: https://doi.org/10.1016/j.pacfin.200 $\underline{4.12 .001}$

Cheung, Y., Connelly, J.T., Jiang, P., \& Limpaphayom, P. (2011). Does Corporate Governance Predict 
Future Performance: Evidence from Hong Kong. Financial Management, 40(1), 159-197. Diakses dari https://www.researchgate.net/public ation/227373497_Does_Corporate Governance_Predict_Future_Perfor mance_Evidence_from_Hong_Kon g

Clacher, I., Doriye, E., \& Hillier, D. (2008). Does Corporate Governance Matter? New Evidence from the United Kingdom. Working Paper. University of Leeds, Leeds.

Doost, R. K., \& Fishman, T. (2004). Beyond Arthur Anderson: Searching for Answers. Managerial Auditing Journal. 19(5), 623-639. doi:

https://doi.org/10.1108/0268690041 0537757

Forum for Corporate Governance in Indonesia. (2001). Tata Kelola Perusahaan. Jakarta: Seri Tata Kelola Perusahaan. Jilid I, Edisi ke3.

Ghazali, N. A. M. (2010). Ownership Structure, Corporate Governance, and Corporate Performance in Malaysia. International Journal of Commerce and Management, Vol. 20(2), 109-119. doi: https://doi.org/10.1108/1056921101 1057245

Haat, M. H. C., Rahman, R. A. \& Mahenthiran, S. (2008). Corporate Governance, Transparency, and Performance of Malaysian Companies. Malaysian of Auditing Journal, 23(8), 744-778. doi:

https://doi.org/10.1108/0268690081 $\underline{0899518}$

Haji, A. A. \& Mubaraq, S. (2015). The Implications of the Revised Code of Corporate Governance on Firm
Performance. Journal of Accounting in Emerging Economies, 5(3), 350380. doi: https://doi.org/10.1108/JAEE-112012-0048

Keputusan Manteri BUMN Nomor: Kep117/M/MBU/2002 pasal 1 tentang penerapan praktik Good Corporate Governance pada Badan Usaha Milik Negara (BUMN).

Kitchenham, B. (2011). Guidelines for Performing Systematic Literature Reviews in Software Engineering. EBSE Technical Report, School of Computer Science and Mathematics. Keele University. UK, 1-57.

Kumar, N. \& Singh, J. P. (2013). Effect of Board Size and Promoter Ownership on Firm Value: Some Empirical Findings from India. Corporate Governance: The International Journal of Business in Society, 13(1). 88-98. doi: https://doi.org/10.1108/1472070131 1302431

Kyereboah-Coleman, A. (2007). Corporate Governance and Firm Performance in Africa: A Dynamic Panel Data Analysis. Paper Presented at the International Conference on Corporate Governance in Emerging Markets. Sabani University, Istanbul, November 15-17. Diakses dari https://pdfs.semanticscholar.org/14 ae/1ccbacaced1dce3c9003b61e3f73 b1cee543.pdf

Lam, T.Y. \& Lee, S.K. (2012). Family Ownership, Board Committees, and Firm Performance: Evidence from Hong Kong. Corporate Governance: The International Journal of Business in Society, 12(3), 353-366. doi: https://doi.org/10.1108/1472070121 1234609 
Leng, A. C. A. \& Mansor, S. A. (2005). Can Good Corporate Governance Practices Contribute to Firms Financial Performance? Evidence from Malaysian Companies. International Journal of Business, Governance, and Ethics, 1(4). 350362.

doi: https://doi.org/10.1504/IJBGE.2005 .006717

Mak, Y. T., \& Kusnadi, Y. (2005). Size Really Matters: Further Evidence on The Negative Relationship Between Board Size and Firm Value. PacificBasin Finance Journal, 13(3), 301318.

doi: https://doi.org/10.2139/ssrn.303505

Mardjono, M. (2006). A Tale of Corporate Governance: Lessons Why Firms Fail. Managerial Auditing Journal, 20(3), 272-283. doi: https://doi.org/10.1108/0268690051 $\underline{0585609}$

Maury, B. (2006). Family Ownership and Firm Performance: Empirical Evidence from Western European Corporations. Journal of Corporate Finance, 12(2), 321-341. doi: https://doi.org/10.1016/j.jcorpfin.20 $\underline{05.02 .002}$

Petersen, K. et al. (2008). Systematic Mapping Studies in Software Engineering. 12th International Conference on Evaluation and Assessment in software engineering, p.1. Diakses dari http://www.robertfeldt.net/publicati ons/petersen_ease08_sysmap_studi es_in_se.pdf

Rashid, K., and Islam, S.M.N. (2013). Corporate Governance, Complementarities, and The Value of A Firm in An Emerging Market: The Effect of Market Imperfections. Corporate Governance: The International Journal of Business in Society, 13(1), 70-87. doi: https://doi.org/10.1108/1472070131 $\underline{1302422}$

Sheikh, N. A., Wang, Z., \& Khan, S. (2013). The Impact of Internal Attributes of Corporate Governance on Firm Performance: Evidence from Pakistan. International Journal of Commerce and Management, 23(1), 38-55. doi: https://doi.org/10.1108/10569 $\underline{211311301420}$

Siagian, F., Siregar, S.V., \& Rahadian, Y. (2013). Corporate Governance, Reporting Quality, and Firm Value: Evidence from Indonesia. Journal of Accounting in Emerging Economies, 13(13), 4-20. doi: https://doi.org/10.1108/2044083131 $\underline{1287673}$

Sun, Q., Tong W. H. S. and Tong, J. (2002). How does Government Ownership Affect Firm Performance? Evidence from China's Privatization Experience. Journal of Business Finance and Accounting, 29(1-2), 1-27. doi: https://doi.org/10.1111/14685957.00422

Tunggal, A. W. (2012). Intisari Internal Auditing. Jakarta: Harvarindo.

Ujunwa, A. (2012). Board Characteristics and the Financial Performance of Nigerian Quoted Firms. Corporate Governance: The International Journal of Business in Society, 12(5), 656-674. doi: https://doi.org/10.1108/1472070121 $\underline{1275587}$

Wieringa, R., Maiden, N., Mead, N., \& Rolland, C. (2005). Requirements Engineering Paper Classification and Evaluation Criteria: A Proposal and A Discussion. Journal Requirement Engineering, 11(1), 102-107. doi: https://doi.org/10.1007/s00766005-0021-6 
Williams, D. R., Duncan, W. J., Ginter, P. M., \& Shewchuk, R. M. (2006). Do Governance, Equity Characteristics, and Venture Capital Involvement Affect Long-Term Wealth Creation in US Health Care and Biotechnology IPOs?. Journal of Health Care Finance, 33(1), 54-71. Diakses dari https://www.ncbi.nlm.nih.gov/pub $\mathrm{med} / 21110493$
Yammeesri, J. \& Herath, S. K. (2010). Board Characteristics and Corporate Value: Evidence from Thailand. Corporate Governance: The International Journal of Business in Society, 10(3), 279-292. doi: https://doi.org/10.1108/1472070101 $\underline{1051910}$ 